\title{
MILENIAL INTERESTS ON ISLAMIC INSURANCE: THE ROLE OF MOBILE SERVICE AND SATISFACTION
}

\author{
Leviana Belianti ${ }^{*}$, Fathimah Awliyaul Alim², Hizrina Awaliyah ${ }^{3}$ \\ 1,2,3Politeknik Negeri Bandung \\ Email: leviana.belianti.ksy16@polban.ac.id (correspondence author)
}

\begin{abstract}
This research aims to predict millennial interest in using sharia insurance product mobile services in terms of usability dimensions (Safe, Convenient, Practical) and attractiveness (Visual, Price, Product) dimensions to interest in sharia insurance products through satisfaction mediation. This research observes 212 millennial respondents aged 20-37 years. By utilizing the SEM-PLS method, this research examines the feasibility of models and hypotheses. Estimation results reveal that millennials are interested in Islamic insurance mobile services based on the quality of practical and convenient mobile services, which has a positive value on satisfaction and interest in using Islamic insurance product mobile services. Thus, this research succeeded in renewing the view of the interests of insurance millennials. This research suggests the importance of the Islamic insurance industry in developing strategies designed to engage millennial customers with better service and increase their confidence in Islamic insurance mobile services.
\end{abstract}

Keywords:Interests, Millennials, Islamic Insurance, Online, and Satisfaction. 


\section{Introduction}

Islamic insurance literacy and inclusion index in Indonesia is still low, at only $2.51 \%$. The Indonesian Sharia Insurance Association (AASI) states that out of 1,000 Indonesians, only 25 people understand and understand sharia insurance. That is what underlies the $5 \%$ share of the Islamic insurance market, even though the majority of the Motherland is occupied by Muslim communities based on The Pew Research Center's Forum on Religion \& Public Life, Indonesia is perched as the country with the most Muslim population in the world, at $87.2 \%$ of the total population.

The low understanding of takaful does not only occur in Indonesia. In Pakistan, insurance customers revealed that the majority of respondents (91\%) did not know the Takāful concept (Akhter and Hussain 2012). The lack of regulating guidelines for Takaful companies in Bangladesh causes many of the operational problems of takaful itself (Khan, 2018). In America too, purchase intentions for Takaful are found to be lower when products are presented to subjects as Islamic (Schmidt 2019).

Population of Indonesia is 264.16 million people, of course including millennials, is related to the generation born between the 1980s and 2000s, the life of a generation that cannot be separated from information technology, especially the internet (KBBI). Quoting data from the Association of Indonesian Internet Service Providers (APJII), internet user penetration in 2018 was 171.17 million of Indonesia's total population of 264.16 million people connected to the internet. The number grew by $27,916,716$ internet users which developed during 2017-2018. The biggest contribution came from Java, namely 55.7 percent, and the penetration of internet users in 2018 was dominated by people aged 15-19 years, overall the age range of 15-39 years was classified as millennial. This opportunity underlies the importance of research on millennial interest in sharia insurance based on the quality of mobile services, a device that has become a breath for millennial generations, with the hope of boosting sharia insurance institutions to transform and glance at millennials for sharia insurance.

The development of research on takaful or sharia insurance emerged in various countries. Tunisians are willing to use sharia insurance services because service compatibility is a determining factor in their decisions (Echchabi, Olorogun, and Azouzi 2014). In Thailand, understanding of Takaful influences the interest of the community to use family Takaful (Ha, Ab Rahman, and Seman 2018). The takaful insurance industry at GCC is very technical and very efficient technically. The UAE and Qatar score the highest technical efficiency, while Saudi Arabia and the UAE are the most costeffective among the GCC countries (Al-Amri 2015). Another study shows that the relationship between demand for Takaful families in MENA and Islamic banking 
deposits, education, level of dependency, women's life expectancy and Muslim population is significantly positive (Sherif and Hussnain 2017).

Looking at the various sources found, there has been no research linking the quality of mobile services with the interest of Islamic insurance with millennial satisfaction intermediaries. This study seeks to adopt findings that investigate the multidimensional concept of mobile banking based on service quality that affects customer confidence and satisfaction (Arcand et al. 2017). This research seeks to predict millennial interest in sharia insurance based on mobile services (security / privacy, practicality, comfort, aesthetics / visuals, price and product attractiveness) which are linked to satisfaction. The aim is to provide a better understanding of how the quality of cellular services through portable devices can improve customer relationships and Islamic insurance institutions. This study will contribute to the sharia insurance marketing literature to broaden the scope of marketing relationships and knowledge of service quality, especially in millennials. The findings will help sharia insurance institutions develop strategies designed to engage millennial customers with better services and increase their confidence in sharia mobile insurance services. This paper consists of four parts. The first presents the conceptual background, the variables studied and the hypotheses tested. The second detail, research methods and data collection. The third presents the findings. The fourth and final section discusses the implications of the findings, shows the limitations of the study and provides suggestions for future research.

\section{Literature Review}

By reviewing the literature, this paper connects the quality of mobile services with the multidimensional scale which is divided into usability dimensions (Safe, Comfortable, Practical) and attractiveness dimensions (Price, Visual, Products) as well as satisfaction with millennial interest in using Sharia Insurance products. The following concepts will be defined between these relationships.

\subsection{Millennial and interest in Islamic insurance}

Millennial. Millennial is related to the generation born between the 1980s and 2000 s. Several birth years that identify millennial generation, for example the mid-1970s to 2004 (Masnick 2012), 1980-1997 (Pew Research Center 2010), 1982-2004 (Howe and Strauss 2000) and 1980-2004 (Weinbaum, Girven, and Oberholtzer 2016). In this study, millennial generation is determined by birth years 1980-2000. Millennial life cannot be separated from information technology, especially the internet (KBBI). Quoting data from the Association of Indonesian Internet Service Providers (APJII), the penetration of internet users in 2018 was 171.17 million of the total Indonesian population, connected to the 
internet. The number grew by $27,916,716$ internet users which developed during $2017-$ 2018. The biggest contribution came from Java, namely 55.7 percent, and the penetration of internet users in 2018 was dominated by people aged 15-19 years, overall the age range of 15-39 years was classified as millennial. Based on Accenture's survey in 2016, all forms of millennial transactions today cannot be separated from online and digital channels. With massive millennial opportunities using the internet, any service strategy besides being made sharia must also be millennial friendly.

\subsection{Islamic insurance (Takaful)}

Islamic insurance is the embodiment of the division of responsibilities, beneficiaries, and solidarity builders. Takaful means helping and mitigating. Because in essence all humans have the risk of life and all their wealth (Ayub 2007). Takaful adopted the Tabarru agreement ', based on mutual responsibility and risk sharing to protect each other (Ha, Ab Rahman, and Seman 2018). The Financial Services Authority (OJK) noted that sharia insurance assets at the end of March 2019 reached Rp43.43 trillion, growing 3.52\% from last year. Furthermore, Deputy Commissioner for OJK II IKNB Superintendent Mochammad Ihsanuddin asserted, this year's target of sharia insurance premium contributions which was originally Rp 15.35 trillion to Rp 16.96 trillion.

\subsection{Interest}

Interest means the tendency of the heart, a high desire for something (KBBI). This research wants to find out how millennial interest in sharia insurance is based on satisfaction seen from the quality of technology service utilization, namely mobile services.

\subsection{Mobile service quality and satisfaction}

Many empirical studies have been carried out by various sectors, one of which is the financial services industry discussing the positive impact of customer satisfaction. Concrete portable services refer to interactions that connect customers / customers with service providers via mobile devices such as mobile phones, smartphones or those we know as smartphones, or personal digital assistants (Karjaluoto, Laukkanen, and Kiviniemi 2010). To improve and retain mobile service customers, service providers must develop selected mobility strategies such as highlighting and promoting the benefits and value of mobile services. (Laukkanen 2016). It will be an advantage to use mobile transactions that make it easier for sharia insurance customers and institutions to make transactions anytime and anywhere as long as they are connected online.

\subsection{Dimensions of Use and satisfaction}


Security is a condition free from danger, disturbance, and all forms of crime (KBBI). Digital footprints that contain personal information, there is a risk or cyber crime that can attack online users and mobile devices. Risks associated with mobile payments involve cost risks and privacy risks (De Kerviler, Demoulin, and Zidda 2016). In other words, before adopting sharia insurance mobile services, consumers must consider it safe to use. Looking at the relationship quality perspective, it is proven that security / privacy has a positive value on e-trust (Casaló, Flavián, and Guinalíu 2008; Kim, Kim, and An 2003; Rajaobelina et al. 2014). Transaction security in an electronic environment has also proven to be important as a predictor of mobile service satisfaction (Szymanski and Hise 2000), especially in the field of industrial financial services (Liao and Cheung 2008). Another study states, there is a trade-off between the perception of comfort and safety in the assessment of young (millennial) consumers of services (Rehncrona 2018). Arcand in his research emphasized that the security or privacy of customer data is important to build trust in banking senvice providers. Therefore, this study put forward the following hypothesis:

H1. Satisfaction Able to Mediate between Security and Interest in Islamic Insurance. Practicality

Practicality is defined as ease and pleasure when running it (KBBI). A rapid advancement of mobile services connected online does not only benefit customers, but also benefits service providers, where they can offer other services of products that are of interest to customers, which then cut costs. Generally discussed, the majority of the financial industry has realized the importance of digital-based services and has begun to shape e-mobile-based services as a channel for transactions. The dimensions of mobile service quality have a positive impact on the trust and satisfaction associated with safety and practicality (Arcand et al. 2017). Ease of use and usability affects millennial satisfaction and intention to use mobile application services (Leon 2018). The research hypothesis is as follows:

H2. Satisfaction Able to Mediate Practicality and Interest in Sharia Insurance.

\section{Comfort}

Comfort is a state of calm, calm, and peace (KBBI) which is a result of fulfilling other values. Convenience in transacting mobile services can be obtained from the efficiency and effectiveness of the service itself. Customers do not need to come to the sharia insurance office because they can access it via portable devices in completing a transaction. Opportunity costs will be reduced, being friendly to customers and that can be described as a convenience. Interaction in a service is very influential to cause comfort (e Sá and Cunha 2019), a comfortable service will mediate satisfaction (Kaura 
et al., 2015), also impact on customer loyalty (Hoang 2019). So the research hypothesis is:

H3. Satisfaction Able to Mediate Comfort and Interest in Islamic Insurance. Price

Price is the prevailing value or other medium of exchange that must be paid at a certain time and in a certain market for the benefit of ownership or use of products or services (KBBI; (Kotler and Armstrong 2010)). Customers in the banking industry regularly look for and determine the banks that provide the highest level of profitability of their products, services and investments, with the lowest cost burden. There must always be a balance between costs and benefits for clients to optimize their interest in this aspect (Mittal and Frennea 2010).

Financial service institutions that review the interests of their customers will always apply fair prices. Research has shown that the customer's decision to accept the price of a product or service has a direct and indirect relationship to the level of satisfaction and loyalty (Estalami et al. 2007). Therefore, the banking and non-banking financial industries, especially Islamic insurance institutions, must always aim to apply fair prices and choose a level of profitability that adds value to customers and increases satisfaction and increases their sense of loyalty. In consideration of the existing literature, this study put forward the following hypothesis:

H4. Satisfaction Able to Mediate Price and Interest in Islamic Insurance.

\section{Visual}

Visual means that it can be seen with the sense of sight (KBBI) in this context associated with the aesthetic value of the content and function presented in a portable device that examines the beauty and human response to it. Graphical appearance will attract the attention of consumers as the presence of an image of a brand, by improving website design (Hausman and Siekpe 2009). The results of other studies show that design aesthetics have positive effects on functional, emotional, social and epistemic values. In turn, this value dimension positively influences the intention to adopt mobile banking (Chaovali et al. 2019). Aesthetic preferences on mobile applications for hospitality indicate that it positively influences their brand engagement and loyalty behavior (J. Lee and Lee 2018). Kim et al. (2003) observed a positive relationship between website design and satisfaction (Kim, Kim, and An 2003). So, the proposed hypothesis is:

H5. Satisfaction Able to Mediate between Visual and Interest in Islamic Insurance. 
Products are goods or services that are made and added to their value or value in the production process and become the final result of the production process (KBBI). Inappropriate product recommendations affect the behavioral intentions of prospective customers (Tseng, Kang, and Chung 2016). The concept of takaful products is based on mutual cooperation, hence it is believed that Islamic insurance institutions must offer products that are affordable by people on low incomes (Htay, Sadzali, and Amin 2015). Islamic insurance institutions must be careful with regard to the level of transaction costs that they provide to their customers to provide an attractive distribution of results (Schmeiser and Wagner 2016). A successful company is a company that provides products and services to be faced with a variety of expectations and succeeded in providing customer satisfaction with the ultimate goal of getting loyal customers in the long run. (Taylor and Baker 1994; Cronin Jr and Taylor 1992). Therefore, this research put forward the following hypothesis:

H6. Satisfaction Able to Mediate between Product and Interest in Islamic Insurance.

\section{Satisfaction}

Satisfaction is a state of fulfilling expectations, desires, or having pleasure (KBBI). Satisfaction is considered to be the result of a comparison between actual performance and expectations regarding a company, "The extent to which the benefits actually received meet or exceed the levels considered to be fair benefits" (Gruen, 1995). The influence of service quality is felt directly and indirectly by customers. This is obtained through customer satisfaction and trust so that they are loyal (Boonlertvanich 2019). Other research shows that the relationship between the quality of internet banking services, customer satisfaction, and customer loyalty is significant (Amin, 2016), as well as sharia insurance mobile services. The proposed hypothesis is as follows:

H7. Satisfaction Able to Mediate between Service Quality and Interest in Islamic Insurance.

\section{Research Methodology}

The following section details the sampling and data procedures, and presents the measurement scale used in this study.

\subsection{List of Codes and Author Resources}

Table 1 shows that there are 8 types of code with author sources, as follows:

Table 1. List of Codes and Author Resources 


\begin{tabular}{|c|c|c|}
\hline 1 & $\begin{array}{c}\text { PVC } \\
\text { Privacy atau Keamanan }\end{array}$ & $\begin{array}{ll}\text { - } & \text { Isabelle Brun (2017) } \\
\text { - } & \text { Lova Rajaobelina (2017) } \\
\text { - } & \text { Sandrine Prom (2017) } \\
& \text { Sandep (2017) }\end{array}$ \\
\hline 2 & $\begin{array}{c}\text { CNV } \\
\text { Convinient atau Kenyamanan }\end{array}$ & $\begin{array}{ll}\text { - } & \text { Vinita Kaura Ch.S. Durga P.S.S (2015) } \\
\text { - } & \text { Isabelle Brun (2017) } \\
\text { - } & \text { Lova Rajaobelina (2017) } \\
\text { - } & \text { Sandrine Arcand (2017) } \\
\text { - } & \text { Dung Phuom Tep (2017) } \\
\text { - } & \text { Patricia Cunha (2019) } \\
\text { - } & \text { Patricia Moura e Sa (2019) }\end{array}$ \\
\hline 3 & $\begin{array}{c}\text { PTC } \\
\text { Practice atau Praktis }\end{array}$ & $\begin{array}{ll}\text { - } & \text { Muslim Amin (2016) } \\
\text { - } & \text { Isabelle Brun (2017) } \\
\text { - } & \text { Lova Rajaobelina (2017) } \\
\text { - } & \text { Sandrine Prom }(2017) \\
& \text { Sep (2017) }\end{array}$ \\
\hline 4 & $\begin{array}{c}\text { PRC } \\
\text { Price atau Harga }\end{array}$ & $\begin{array}{ll}\text { - } & \text { Vinita Kaura Ch.S. Durga P.S.S (2015) } \\
\text { - } & \text { Adewale Abideen Adeyemi (2018) } \\
\text { - } & \text { Hartomi Maulaulana (2018) } \\
\text { - } & \text { Xiao Tong (2018) }\end{array}$ \\
\hline 5 & $\begin{array}{c}\text { VSL } \\
\text { Visual atau Visual }\end{array}$ & $\begin{array}{ll}\text { - } & \text { Isabelle Brun (2017) } \\
\text { - } & \text { Lova Rajaobelina (2017) } \\
\text { - } & \text { Manon Arcand (2017) } \\
\text { - } & \text { Sandrine Prom Tep (2017) }\end{array}$ \\
\hline 6 & $\begin{array}{c}\text { PRD } \\
\text { Product atau Produk }\end{array}$ & $\begin{array}{ll}\text { - } & \text { Adewale Abideen Adeyemi (2018) } \\
\text { - } & \text { Dzuljastri Abdul Razak (2018) } \\
\text { - } & \text { Hartomi Maulana (2018) } \\
\text { - } & \text { Yuni Lee (2018) } \\
\text { - } & \text { Manisha Sharma (2018) } \\
\text { - } & \text { Sujeet Kumar Sharmaa (2018) }\end{array}$ \\
\hline 7 & $\begin{array}{c}\text { STF } \\
\text { Satisfaction atau Kepuasan }\end{array}$ & $\begin{array}{l}\text { - Amalia Triantafillidou (2014) } \\
\text { - Muslim Amin (2016) }\end{array}$ \\
\hline
\end{tabular}




\begin{tabular}{|c|c|c|}
\hline 8 & $\begin{array}{l}\text { INT } \\
\text { Interest atau Minat }\end{array}$ & $\begin{array}{ll}\text { - } & \text { Amron dan Usman } \\
\text { - } & \text { Ali Mursid } \\
\text { - } & \text { Dzewale Abideen Adeyemi (2018) } \\
\text { - } & \text { Hartomi Maulana (2018) } \\
\text { - } & \text { Manisha Sharma (2018) } \\
\text { - } & \text { Sujeet Kumar Sharmaa (2018) }\end{array}$ \\
\hline
\end{tabular}

\subsection{Samples, procedures and data collection}

The research sample consisted of 212 millennial respondents ranging in age from 2037 years old users of mobile sites or mobile applications, most of whom were not yet sharia insurance customers. The sampling method used is Nonprobability sampling with a type of purposive sampling that is deemed suitable for research on this matter. Nonprobability sampling is a technique that does not provide equal opportunity or opportunity for each element or member of the population to be selected as a sample. Purposive sampling is a sampling technique with certain considerations where the subject is based on certain characteristics that are considered to have a close connection with the characteristics of the population that have been previously known. In other words, the sample units that are linked are adjusted to certain criteria that are applied based on the research objectives or research problems.

Data collection procedures are carried out by distributing questionnaires online to the people of West Java through Google Form. Google Form also known as Google Formulir is a feature of Google Drive provided by Google to assist users in sending surveys, making it easier to collect information efficiently. This research uses Google Form because millennials are very familiar with this feature. After the target respondent is recorded, the data is processed and tested for eligibility, then it is examined whether the hypotheses designed can be accepted or rejected. After the research is completed, a research report will be made in the form of paper.

\subsection{Model Structure}

The following model structure will be analyzed using the PLS-SEM research method, by testing the level of validity and reliability of data, testing whether the direction of the relationship between variables is positive or negative, and testing whether the relationship between variables is significant or not. 


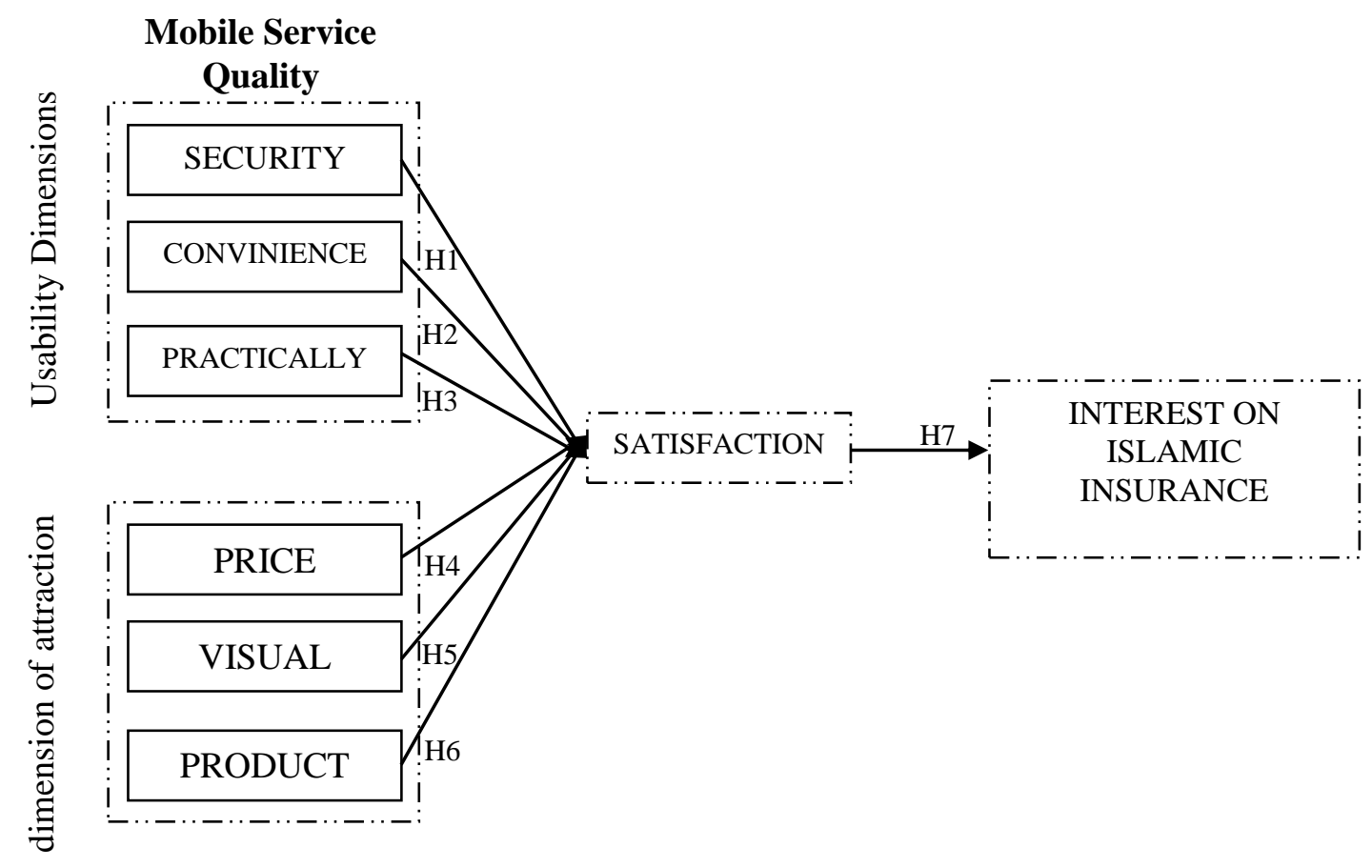

Fig. 1 Model Structure

\section{RESULT AND DISCUSSION}

After testing with the PLS-SEM research method, the following results are obtained:

\subsection{Model Feasibility}

Figure II. shows that the Safety construct (PVC) is measured by 3 indicators, namely $P \vee C$ 1, PVC 2, and PVC 3. Likewise the Comfort construct (CNV) is measured by 5 indicators, namely CNV 1, CNV 2, CNV 3, CNV 4, and CNV 5; Practical construct (PTC) is measured by 5 indicators, namely PTC 1, PTC 2, PTC 3, PTC 4, and PTC 5; Price construct (PRC) is measured by 5 indicators, namely PRC 1, PRC 2, PRC 3, PRC 4, and PRC 5; Visual construct (VSL) is measured by 3 indicators, namely VSL 1, VSL 2, and VSL 3; Product construct (PRD) is measured by 4 indicators, namely PRD 1, PRD 2, PRD 3, and PRD 4; Satisfaction construct (STF) is measured by 5 indicators, namely STF 1, STF2, STF 3 , STF 4, and STF 5; and the construct of Interest (INS) is measured by 4 indicators, namely INS 1, INS 2, INS 3, and INS 4. 


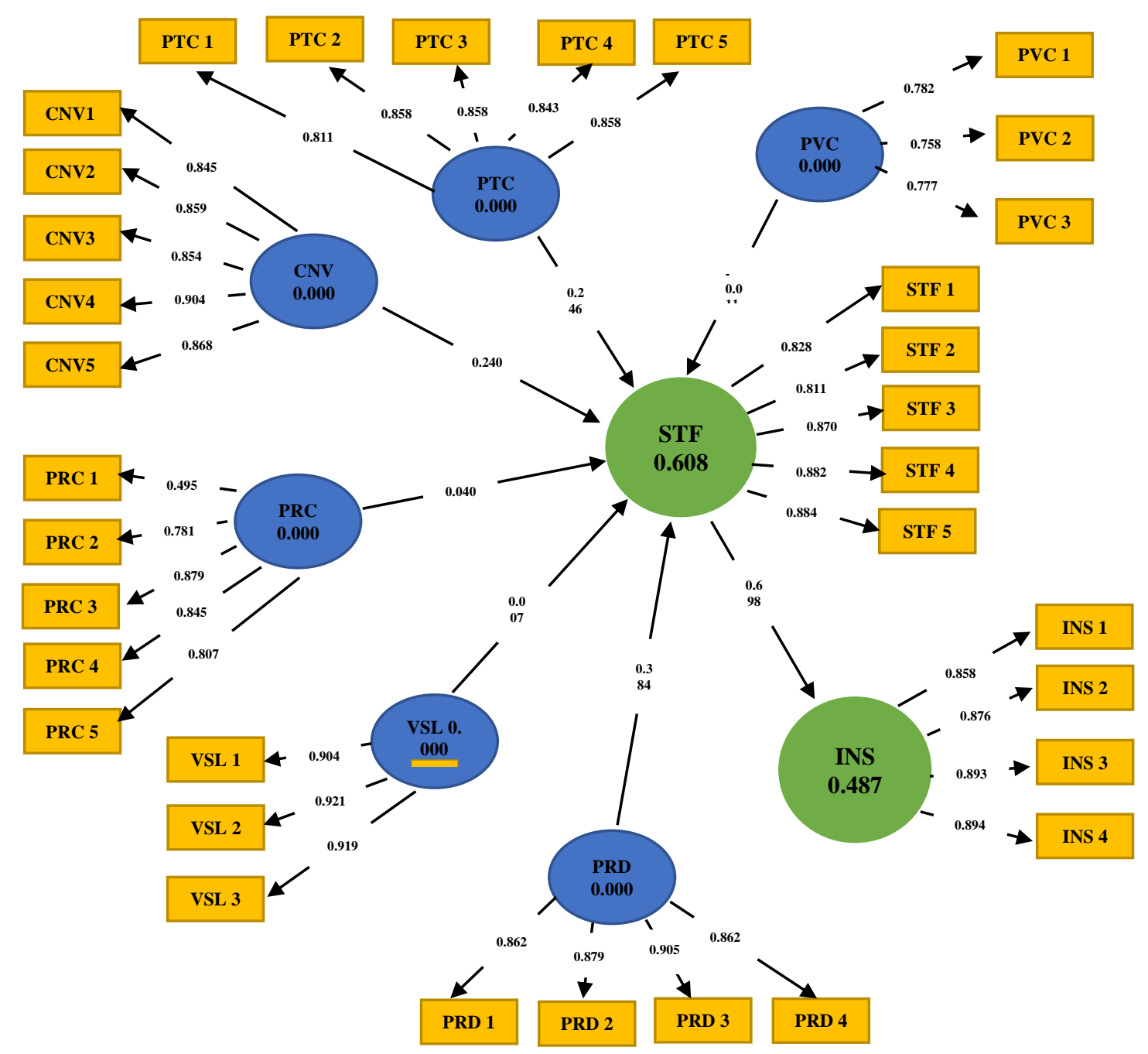

Fig. 2 Model Feasibility Analysis

\subsection{Model Feasibility Test Results}

Table 2. Feasibility Test Result

\begin{tabular}{|l|l|l|l|}
\hline Variabel & AVE & Composite Reliability & Cronbach's Alpha \\
\hline CNV & 0.748887 & 0.937121 & 0.916103 \\
\hline INS & 0.775040 & 0.932327 & 0.903267 \\
\hline PRC & 0.598364 & 0.878256 & 0.825269 \\
\hline PRD & 0.769787 & 0.930409 & 0.900207 \\
\hline PTC & 0.713317 & 0.925570 & 0.899511 \\
\hline PVC & 0.596551 & 0.816011 & 0.665331 \\
\hline STF & 0.752434 & 0.938196 & 0.917765 \\
\hline VSL & 0.836541 & 0.938846 & 0.902369 \\
\hline
\end{tabular}


The feasibility test of this model consists of a validity test, as well as a reliability test. Validity test is obtained from AVE (Average Variance Extracted) value, where the data that is said to be valid are data that obtain test results $>0.5$. While the reliability test was obtained from the Composite Reliability and Cronbach's Alpha values, where the data that was said to be reliable were the data that obtained the Composite Reliability value $\geq 0.6$ and Cronbach's Alpha value $\geq 0.7$.

There are eight variables tested in this study, including CNV (Convenience); INS (Interest / Interest); PRC (Price); PRD (Product); PTC (Practice / Practical); PVC (Privacy / Security); STF (Satisfaction); and VSL (Visual). All variables were tested for eligibility by testing their validity and reliability through PLS-SEM testing. Based on the model feasibility test table above shows that the variables CNV, INS, PRC, PRD, PTC, PVS, STF, and VSL variables obtained the value of $A V E>0.5$; that means that all variables are convergently valid. All variables also obtained Composite Reliability value $\geq 0.6$; and Cronbach's Alpha value $\geq 0.7$; it means that all variables are declared reliable or in other words even though all variables are retested many times, the value obtained will tend to be fixed and consistent. Then it can be concluded that the model feasibility test of all variables tested in this study was declared feasible to be tested because it has a convergent level of validity, and the data are realiable.

\subsection{Coefficient and Hypothesis Analysis}

Figure III. Below are the constructs of Safety (PVC), Convenience (CNV), Practical (PTC), Price (PRC), Visual (VSL), and Product (PRD) whether they have a relationship with the Satisfaction construct (STF), and the Satisfaction construct (STF) STF) examined whether it has a relationship with the construct of Interest (INS). The relationship under study is symbolized by the child in between constructs.

The following picture is the coefficient analysis and hypothesis from this study: 


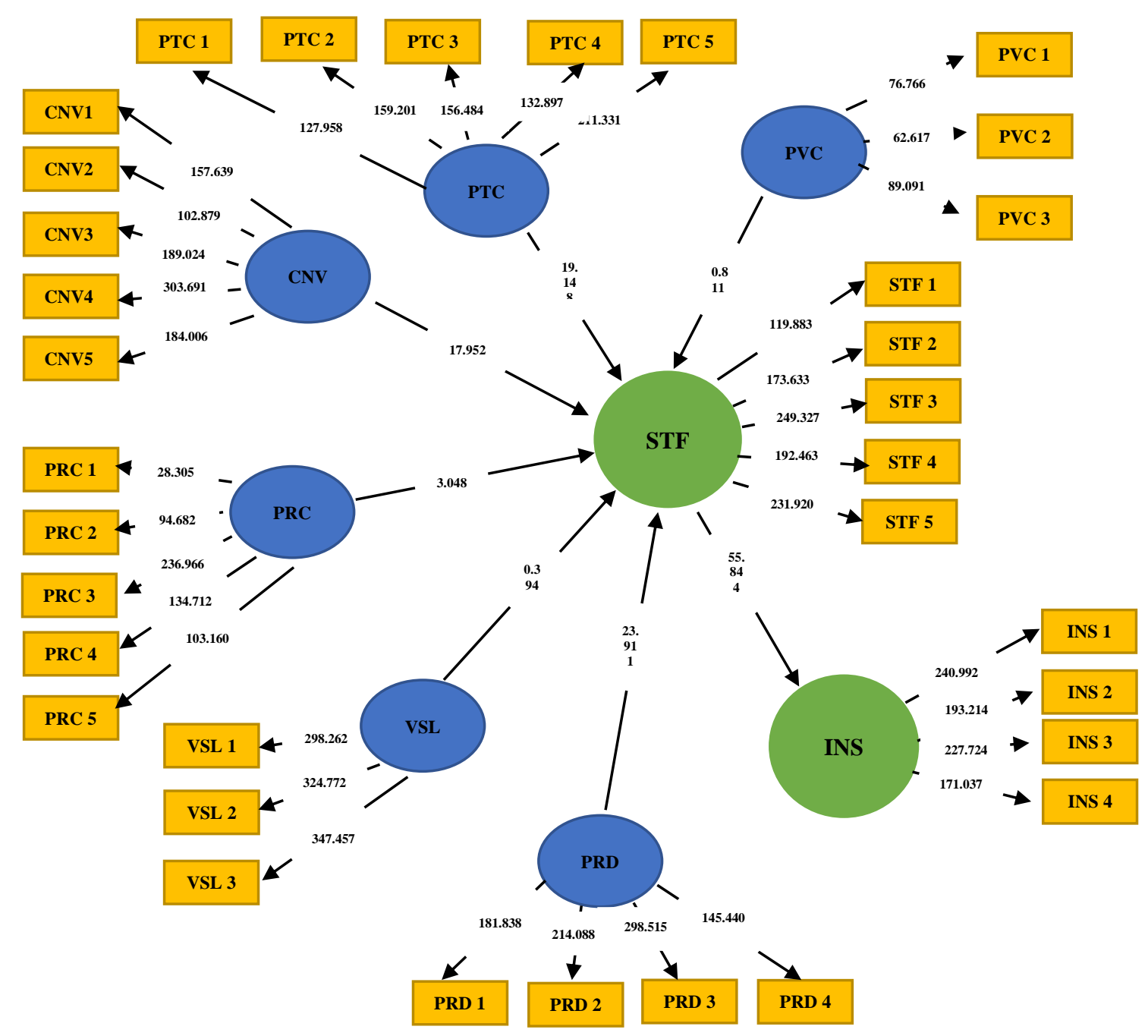

Fig 3. Coefficient and Hypothesis Analysis

\subsection{Coefficient and Hypothesis Test Results}

Table 3. Coefficient and Hyporhesis Test Result

\begin{tabular}{|l|l|l|}
\hline Variabel Correlation & Original Sample (O) & T-Statistics $(\mid \mathbf{O} /$ STERR|) \\
\hline CNV -> STF & 0.239649 & 16.182294 \\
\hline PRC -> STF & 0.039736 & 3.146827 \\
\hline PRD -> STF & 0.383687 & 23.240051 \\
\hline PTC -> STF & 0.245741 & 19.395089 \\
\hline PVC -> STF & -0.011266 & 0.891950 \\
\hline STF -> INS & 0.697550 & 57.046259 \\
\hline VSL -> STF & 0.007369 & 0.399861 \\
\hline
\end{tabular}


In this coefficient and hypothesis test, two things are assessed, namely the direction of the relationship between variables as seen from the value of the Original Sample (O). If the Original Sample $(O)$ is negative then the relationship between variables shows a negative direction, in other words that between variables there is no relationship and does not affect each other. Conversely, if the Original Sample (O) is positive, the relationship between variables shows a positive direction, in other words that between variables there is a relationship and influence each other. To assess the significance of the relationship between variables can be seen from the value of T-Statistics (I O / STERR |). If T-Statistics (| O / STERR |) has value> 1.96; then the relationship between variables is significant and vice versa T-Statistics (| O / STERR |) is worth <1.96; then the relationship between variables is not significant.

Other provisions, if the value of Original Sample $(O)$ is positive, and the value of $T$ Statistics (| O / STERR |)> 1.96; then the hypothesis is accepted, if the value of Original Sample (O) is positive, but the T-Statistics (| O / STERR |) value is <1.96; the hypothesis is accepted provided that the relationship between variables is not significant; and if the Original Sample (O) value is negative, and the T-Statistics (| O / STERR |) value> 1.96; then the hypothesis is rejected because between variables do not significantly influence each other, and if the value of Original Sample $(O)$ is negative, and the value of T-Statistics (| O / STERR || <1.96; then the hypothesis is rejected.

There are seven relationship variables tested, namely CNV -> STF (Comfort effect on Satisfaction); PRC $\rightarrow$ STF (Price affects satisfaction); PRD $\rightarrow$ STF (Product affects Satisfaction); PTC -> STF (Practical effect on Satisfaction); PVC -> STF (Security affects Satisfaction); STF -> INS (Satisfaction influences interest); and VSL -> STF (Visual effect on Satisfaction).

Table 3 above shows that:

1) The relationship between PVC and STF is not significant with a T-statistic of 0.891950 $(<1.96)$. The original sample value is negative that is $(-0.011266)$ which indicates that the direction of the relationship between PVC and STF is negative. Thus the $\mathrm{HI}$ hypothesis in this study which states that "Satisfaction Able to Mediate between Security and Interest in Sharia Insurance Product Mobile Services" is rejected.

2) The relationship between CNV and STF is significant with a T-statistic of 16.182294 (> 1.96). The original sample value is positive that is equal to 0.239649 which indicates that the direction of the relationship between CNV and STF is positive. Thus the H2 hypothesis in this study which states that "Satisfaction Able to Mediate between Comfort and Interest in Sharia Insurance Products" is accepted. 
3) The relationship between PTC and STF is significant with a T-statistic of 19.395089 (> 1.96). The original sample value is positive that is -0.245741 which shows that the direction of the relationship between PTC and STF is positive. Thus the H3 hypothesis in this study which states that "Satisfaction Able to Mediate Between Practical and Interest in Sharia Insurance Products" is accepted.

4) The relationship between PRC and STF is significant with T-statistics of 3.146827 (> 1.96). The original sample value is positive that is equal to 0.039736 which shows that the direction of the relationship between PRC and STF is positive. Thus the H4 hypothesis in this study which states that "Satisfaction Able to Mediate Between Price and Interest in Sharia Insurance Products" is accepted.

5) The relationship between VSL and STF is not significant with a T-statistic of 0.399861 $(<1.96)$. The original sample value is positive that is equal to 0.007369 which indicates that the direction of the relationship between VSL and STF is positive. Thus the H5 hypothesis in this study which states that "Satisfaction is able to mediate between Visual and Interest in Sharia Insurance Products" is accepted with the note that the direction of the relationship between Visual and Satisfaction is positive, but not significant.

6) The relationship between PRD and STF is significant with a T-statistic of 23.240051 (> 1.96). The original sample value is positive that is equal to 0.383687 which indicates that the direction of the relationship between the PRD and the STF is positive. Thus the H6 hypothesis in this study which states that "Satisfaction is able to mediate between products and interests of Islamic insurance products." received.

7) The relationship between STF and INS is significant with a T-statistic of 57.046259 (> 1.96). The original sample value is positive, that is 0.697550 , which shows that the direction of the relationship between STF and INS is positive. Thus the H7 hypothesis in this study which states that "Satisfaction Able to Affect Interest in Sharia Insurance Products" is accepted.

\subsection{Theoretical Implications}

According to a statement from Gruen, 1995: "satisfaction is considered the result of a comparison between actual performance and expectations regarding a company". Many factors can influence the interest of Islamic insurance products through mediation of satisfaction as seen from the dimensions of usability (security, comfort, and practicality) as well as the dimensions of attractiveness (visual, price, and product). But this research proves that not all factors can influence consumers to be satisfied and loyal to the company. The relationship between one of the dimensions of usability, i.e. security, shows a negative relationship, it means that the variables with each other do 
not have any influence. When security is reduced, it is not certain that satisfaction will also decrease. This is not in line with the statement stating that "transaction security in the electronic environment has also proven to be important as a predictor of mobile service satisfaction (Szymanski and Hise 2000), especially in the field of industrial financial services (Liao and Cheung 2008)". So it can be said that the element of security is not important to be able to measure interest in Islamic insurance products through mediation of customer satisfaction with the company.

However, in this research, the dimension of attractiveness, namely the relationship between visual and satisfaction, shows an insignificant relationship, but influences one another. This proves that not always visual or appearance can affect customer satisfaction. So there is a renewal of the theory regarding the interests of Islamic insurance products through mediation of customer satisfaction, namely the absence of safety factors that affect customer satisfaction and interest; and the insignificant influence of the attractive appearance of mobile applications from Islamic insurance companies.

\subsection{Industrial Implications}

Development of strategies designed to engage millennial customers with better services and increase their confidence in sharia mobile insurance services. This research has an important influence on the development of the marketing strategy of the Islamic insurance sector, that consumers are usually motivated to be insured because they are given trust because of the usefulness of the product itself. The industry must not underestimate the importance of the attraction that can be obtained from the interaction of service agents and consumers through mobile devices. Considering that mobile devices currently have a very strong connection, especially with millennials, this representation can also be very connected to the Islamic insurance financial services industry. Possibility of direct contact with representatives of sharia insurance agents with consumers, secure messages, attractive presentations, valid and fast information can be entered into the mobile application to facilitate customers of sharia insurance mobile services. Various e-commerce present such as Tokopedia, Go-Pay, Ovo encourage positive consumer behavior to pay insurance premiums, each of which is a consumer and insurance agency intermediary. In the future, registration and payment of sharia insurance premiums can be done anytime and anywhere without limits on distance, space and time. 


\section{Conclusion}

\subsection{Conclusion}

After data collection and testing, the results obtained that all variables, namely PVC (Safety), CNV (Convenience), PTC (Practical), PRC (Price), VSL (Visual), PRD (Product), STF (Satisfaction), and INS ( Interest) meets the requirements in the model feasibility test by obtaining a value of AVE> 0.5; Composite Reliability $\geq 0.6$; and Cronbach's Alpha value $\geq 0.7$; so that all variables are declared eligible to be tested and examined.

In the coefficient and hypothesis test results are obtained that:

1) There is no relationship between PVC (Security) and STF (Satisfaction), then HI. "Satisfaction Able to Mediate between Security and Interest in Sharia Insurance Products" was rejected.

2) There is a positive relationship between CNV (Comfort) with STF (Satisfaction) significantly, then H2. "Satisfaction Able to Mediate Comfort and Interest in Sharia Insurance Products" is accepted.

3) There is a positive relationship between PTC (Practical) and STF (Satisfaction) significantly, then H3. "Satisfaction Able to Mediate between Practical and Interest in Sharia Insurance Products" was accepted.

4) There is a positive relationship between PRC (Price) and STF (Satisfaction) significantly, then H4. "Satisfaction Able to Mediate Between Price and Interest in Sharia Insurance Products" is accepted.

5) There is a positive relationship between VSL (Visual) and STF (Satisfaction) but not significant, then H5. "Satisfaction Able to Mediate between Visual and Interest in Sharia Insurance Products" is received with a note.

6) There is a positive relationship between PRD (Product) with STF (Satisfaction) significantly, then H6. "Satisfaction Able to Mediate between Products and Interests of Sharia Insurance Products" is accepted.

7) There is a positive relationship between STF (Satisfaction) with INS (Interests) significantly, then H7. "Satisfaction Able to Affect Interest in Sharia Insurance Products" is accepted.

Based on the results of the model feasibility test, as well as the coefficient and hypothesis tests, it can be concluded that research on "Millennial Interest in Sharia Insurance: The Role of Mobile Services and Satisfaction" proves that the prediction of millennial interest in using online Sharia insurance services is based on satisfaction seen from the usability dimension (safety, comfort, and practical) and the dimensions of attractiveness (visual, price, and product) are correct. Security or privacy services need to be improved to gain millennial consumer trust, design / aesthetics influence 
millennial satisfaction with the interest of Islamic insurance, but are not given much attention and are not important outside other factors (product variation and price, practicality and comfort).

\subsection{Limitations and Further Research Suggestions}

This study has limitations that limit the ability of authors to make generalizations based on findings, but provide opportunities for future research. The limitation that the authors encountered at the time of conducting the study was the simple sample size. This is because the scope of sample collection is only for millennial West Java. So the authors suggest for further research, the sample size can be enlarged and the scope of the collection of sample data can be expanded again, namely the Indonesian millennials

\section{REFERENCES}

[1]Akhter, Waheed, and Tajammal Hussain. 2012. "Takāful Standards and Customer Perceptions Affecting Takāful Practices in Pakistan: A Survey." International Journal of Islamic and Middle Eastern Finance and Management.

[2]Al-Amri, Khalid. 2015. "Takaful Insurance Efficiency in the GCC Countries." Humanomics.

[3]Arcand, Manon, Sandrine PromTep, Isabelle Brun, and Lova Rajaobelina. 2017. "Mobile Banking Service Quality and Customer Relationships." International Journal of Bank Marketing.

[4]Ayub, M. 2007. Understanding Is/amic Finance. England: John Wiley \& Sons Ltd.

[5]Boonlertvanich, Karin. 2019. "Service Quality, Satisfaction, Trust, and Loyalty: The Moderating Role of Main-Bank and Wealth Status." International Journal of Bank Marketing.

[6]Casaló, Luis V, Carlos Flavián, and Miguel Guinalíu. 2008. "The Role of Satisfaction and Website Usability in Developing Customer Loyalty and Positive Word- of- mouth in the E- banking Services." International Journal of Bank Marketing.

[7]Chaouali, Walid, Renaud Lunardo, Imene Ben Yahia, Dianne Cyr, and Abdelfattah Triki. 2019. "Design Aesthetics as Drivers of Value in Mobile Banking: Does Customer Happiness Matter?" International Journal of Bank Marketing.

[8]Cronin Jr, J Joseph, and Steven A Taylor. 1992. "Measuring Service Quality: A Reexamination and Extension." Journal of Marketing 56 (3): 55-68.

[9] Sá, Patrícia Moura, and Patrícia Cunha. 2019. "Drivers of Customer Satisfaction and Loyalty in Swimming Pools." The TQM Journal. 
[10]Echchabi, Abdelghani, Lukman Ayinde Olorogun, and Dhekra Azouzi. 2014. "Islamic Insurance Prospects in Tunisia in the Wake of the Jasmine Revolution: A Survey from Customers' Perspective." Journal of Islamic Accounting and Business Research 5 (1): 15-28.

[1 1] Estalami, Hooman, Sarah Maxwell, David Martín- Consuegra, Arturo Molina, and Águeda Esteban. 2007. "An Integrated Model of Price, Satisfaction and Loyalty: An Empirical Analysis in the Service Sector." Journal of Product \& Brand Management.

[12]Ha, Mirwanee, Asmak Ab Rahman, and Azizi Che Seman. 2018. "Society's Understanding of Family Takaful." In New Developments in Islamic Economics. Emerald Publishing Limited.

[13]Hausman, Angela V, and Jeffrey Sam Siekpe. 2009. "The Effect of Web Interface Features on Consumer Online Purchase Intentions." Journal of Business Research 62 (1): 5-13.

[14]Hoang, Dung Phuong. 2019. "The Central Role of Customer Dialogue and Trust in Gaining Bank Loyalty: An Extended SWICS Model." International Journal of Bank Marketing.

[15]Howe, Neil, and William Strauss. 2000. Millennials Rising: The next Great Generation. Vintage.

[16]Htay, Sheila Nu Nu, Nur Shazwani Sadzali, and Hanudin Amin. 2015. "An Analysis of the Viability of Micro Health Takaful in Malaysia." Qualitative Research in Financial Markets.

[17]Karjaluoto, Heikki, Tommi Laukkanen, and Vesa Kiviniemi. 2010. "The Role of Information in Mobile Banking Resistance." International Journal of Bank Marketing.

[18]Kerviler, Gwarlann De, Nathalie T M Demoulin, and Pietro Zidda. 2016. "Adoption of In-Store Mobile Payment: Are Perceived Risk and Convenience the Only Drivers?" Journal of Retailing and Consumer Services 31: 334-44.

[19]Kim, Hong- bumm, Woo Gon Kim, and Jeong A An. 2003. "The Effect of Consumer- based Brand Equity on Firms' Financial Performance." Journal of Consumer Marketing.

[20]Kotler, Philip, and Gary Armstrong. 2010. "Principles of Marketing,(Thirteen Edition)." New Jersey, NJ: Pearson Prentice Hall.

[21]Laukkanen, Tommi. 2016. "Consumer Adoption versus Rejection Decisions in Seemingly Similar Service Innovations: The Case of the Internet and Mobile Banking." Journal of Business Research 69 (7): 2432-39.

[22]Lee, Jihyun, and Yuri Lee. 2018. "Effects of Multi-Brand Company's CSR Activities on Purchase Intention through a Mediating Role of Corporate Image and Brand 
Image." Journal of Fashion Marketing and Management: An International Journal. [23]Lee, Seonjeong Ally. 2018. "M-Servicescape: Effects of the Hotel Mobile App Servicescape Preferences on Customer Response." Journal of Hospitality and Tourism Technology.

[24]Leon, Steven. 2018. "Service Mobile Apps: A Millennial Generation Perspective." Industrial Management \& Data Systems.

[25]Liao, Ziqi, and Michael Tow Cheung. 2008. "Measuring Consumer Satisfaction in Internet Banking: A Core Framework." Communications of the ACM 51 (4): 47-51.

[26]Masnick, George. 2012. "Defining the Generations." Retrieved from Housing Perspective: Research, Trends, and Perspective from The Harvard Joint Center for Housing Studies: Http://Housingperspectives. Blogspot. Co. Id/2012/11/DefiningGenerations. Html.

[27]Mittal, Vikas, and Carly Frennea. 2010. "Customer Satisfaction: A Strategic Review and Guidelines for Managers." MSI Fast Forward Series, Marketing Science Institute, Cambridge, MA.

[28]Pew Research Center. 2010. "Millenials: A Portrait of Generation Next: Confident. Connected." 2010. http://www.pewsocialtrens.org/files/2010/10/millennialsconfident-connected-open-to-change.pdf.

[29]Rajaobelina, Lova, Line Ricard, Jasmin Bergeron, and Élissar Toufaily. 2014. "An Integrative Model of Installed Online Trust in the Financial Services Industry." Journal of Financial Services Marketing 19 (3): 186-97.

[30]Rehncrona, Carin. 2018. "Young Consumers' Valuations of New Payment Services." International Journal of Quality and Service Sciences.

[31]Schmeiser, Hato, and Joël Wagner. 2016. "What Transaction Costs Are Acceptable in Life Insurance Products from the Policyholders' Viewpoint?" The Journal of Risk Finance.

[32]Schmidt, Alex Paton. 2019. "The Impact of Cognitive Style, Consumer Demographics and Cultural Values on the Acceptance of Islamic Insurance Products among American Consumers." International Journal of Bank Marketing.

[33]Sherif, Mohamed, and Sadia Hussnain. 2017. "Family Takaful in Developing Countries: The Case of Middle East and North Africa (MENA)." International Journal of Islamic and Middle Eastern Finance and Management.

[34]Szymanski, David M, and Richard T Hise. 2000. "E-Satisfaction: An Initial Examination." Journal of Retailing 76 (3): 309-22.

[35]Taylor, Steven A, and Thomas L Baker. 1994. "An Assessment of the Relationship between Service Quality and Customer Satisfaction in the Formation of 
Consumers' Purchase Intentions." Journal of Retailing 70 (2): 163-78.

[36]Tseng, Lu-Ming, Yue-Min Kang, and Chi-Erh Chung. 2016. "The Insurance Agents' Intention to Make Inappropriate Product Recommendations." Journal of Financial Regulation and Compliance.

[37] Weinbaum, Cortney, Richard S Girven, and Jenny Oberholtzer. 2016. The Millennial Generation: Implications for the Intelligence and Policy Communities. Rand Corporation. 